\title{
Creating Travel Literature: The Case of Paul Kane
}

\author{
I.S. MacLaren
}

As more and more research occurs into published English-language travel literature, the production of individual texts, rather than their authorship alone, demands attention. Both the unreliability of the text as entirely the traveller's or explorer's own and the question of whether or not the text narrates only his own experience and observations have made problematical the matter of interpretation. Recently, Percy G. Adams has shown in Travel Literature and the Evolution of the Novel (1983) how, because travel writing issued often enough from writers who did no more than move around in an armchair, this genre and the novel grew indistinguishable for a time in the early eighteenth century. From then on, travel literature would often exemplify a more complex, or at least less straightforward, relation between experience and language than one might expect. This relation grew for itself new layers of complexity with other literary developments in the late eighteenth century and later: increased emphasis shifted to the traveller's sentimental response to nature ${ }^{1}$ and then, with the rise of the Victorian naturalist's curiosity, back again to the empirical record itself, with, however insouciantly, the perpetration of an objective, unbiased recorder as narrator. ${ }^{2}$

Through these changes the fundamental authority of language as a way of seeing and testifying did not waver, although questions arose over the peril that might attend divergences from the plain style into metaphorical language. But if the authority of language did not waver, bibliographical study shows that the apparently strict correspondence between experience and literary record could often have been called into question. Because it was not, the study today of travel literature, before it embarks on interpretation, must ask, text by text, whose language books of travel and exploration deploy. Of course the answer will vary considerably, but it does appear

\footnotetext{
An earlier version of this paper was given at the $43 \mathrm{~d}$ Annual Meeting of the Bibliographical Society of Canada held at the University of Windsor, Windsor, Ontario, on 3 I May 1988.
} 
clear that publishers of the period exerted severe control over the travel literature market. In both London and Philadelphia, they took very great care to ensure that the record of one's travels met the expectations of the reading public. One must not underestimate the changes that could occur when a travel journal metamorphosed into a publishable commodity. Just as the perceptual baggage packed by the explorer or traveller influenced significantly the narrative expression of his journal, ${ }^{3}$ so the revisions made to the journal, either by him or for him upon his return home, significantly assisted the creation of the publishable commodity.

After all, a late eighteenth-century publisher still enjoyed almost a tyrant's business relation with authors, ${ }^{4}$ especially with authors who were expected to produce only one book. The publisher often made his largest profits from this best selling genre (Samuel Hearne received $£ 200$ for his manuscript in I792; eleven years later, Jane Austen received only ten for the first draft of Northanger Abbey. ${ }^{5}$ It made little business sense for a publisher to allow a book to diverge in style or convention any more than absolutely necessary from the profitable norms that the purchasing public tolerated. Moreover, and this point will be expanded later, even in the case of journals that had already passed muster before such institutions as the British Admiralty, publishers such as John Murray, a leader in the production of books of travel and exploration, never hesitated to shape the field journal into their standard formats and sentence structures. ${ }^{6}$

Briefly, before moving on to the case of Paul Kane's narrative, this essay will place on view several examples of pre-publication intervention / alteration in order to recapitulate the possible range of rewriting practised in the publishing trade between the middle of the eighteenth and the middle of the nineteenth centuries. The first case is Samuel Hearne's narrative. Hearne spent twenty-four years preparing for publication in 1795 the account of his remarkable pedestrian explorations in 1769 -I77I over the arctic mainland tundra. When the work finally appeared more than two years after his death as A Journey from Prince of Wales's Fort in Hudson's Bay to the Northern Ocean 1769, 1770, 1771, 1772, it had been re-written, mostly by Hearne, from his original journals. ${ }^{7}$ Because it is clear that certain passages were written as much as two decades after the trips, one must allow that the detectable dualism in the narrative persona may or may not have been produced by a single author. Where some passages maintain the immediacy of on-the-spot observation and response, others betray another persona entirely, a retrospective one, as in the conclusion to the book's most memorable moment, the massacre at Bloody Fall of a sleeping camp of Inuit by Hearne's Amerindian guides: 'even at this hour I cannot reflect on the transactions of that horrid day without shedding tears. ${ }^{8}$ The sentimental traveller suddenly bursts from the present into the 
set dramatic scene, the whole of which was added to the original journals at a later date. ${ }^{9}$

It remains unclear whether or not the entire massacre passage was penned, or suggested, by another writer. What is known is that the manuscript had benefited from the assistance of two people: Dr. John Douglas and William Wales. Douglas, Canon of St. Paul's, had been engaged by Lord Sandwich to ready for publication Captain Cook's journals from his fateful third Pacific voyage. Wales, an astonomer famous in his day, was known to Hearne as a visitor to Prince of Wales's Fort even before Hearne's explorations in 1769 . Wales had served on Cook's second Pacific voyage. (Literary history remembers him best as one of Coleridge's teachers at charity school.) Carefully structured, the massacre scene bears many of the late eighteenth century's hallmarks of the sublime: ${ }^{10}$ the depiction of the Chipewyans as banditti, the sublime flourishes of the description of the tundra (especially the waterfall), the use of chiaroscuro to dramatize the ambush, the dramatic suspense effected in the narrative just prior to the onslaught, the focus on the eighteen-year-old Inuit girl, who seems to pop straight onto the tundra from a contemporary gothic novel, and the heightened emphasis on the traveller's / narrator's own sensibilities as, 'neuter in the rear,' he views the pogrom. Perhaps the most exaggerated of these sublime qualities is the problematical use of chiaroscuro: although the scene is set in the Radcliffian gloom of I:OO A.M. against the backdrop of a barely visible though deafening falls, only a few pages later, the awful effect is contradicted outright by the information that the sun does not set at the mouth of the Coppermine River in the month of July. Here, then, either Hearne, writing at two different stages in his career, or altogether another hand makes a bald testament of fact clash quite wonderfully with conventional aesthetic parlance in a way that anticipates the pattern of travel writing in the unsettled parts of North America over the next half century. This fissure between the document and the metaphor, between the world as scientifically identifiable and the world as conventionally represented through set canons, constitutes an essential paradigm of the period's travel literature, not only in the United States - Fender's superb work has located it in American travel literature - but, I think, wherever in the world the late eighteenth-century and early nineteenth-century European dualism existed between the search for the new but the registration of it in terms of the Old World.

Hearne's understandable hesitation about publishing - his findings had already been reported and criticized at length - testifies to the difficulty anyone has in giving shape to experience that lies apparently outside the comprehension of life. Indeed, Hearne's hesitation may well be regarded as anticipatory of the same experience undergone by Charles Darwin. The 
Victorian naturalist spent two decades and much anguish himself before publishing a full articulation of his discoveries, realizing that the expression of his findings in Old World language and schemata was not possible. In the end, On the Origin of Species (1859) articulated the stunning implications in a new language - the principle of natural selection - a language which, as Darwin had feared, was not well understood.

A much more typical dualism than either Hearne's or Darwin's would occur in the period between the publication of their works. It occurred at the instigation either of author or publisher, but the result often appeared similar. This was the engagement of the ghost writer. Alexander Bicknell, for example, 'edited' Jonathan Carver's journals - near contemporaries of Hearne's - to the extent that John Parker and the Minnesota Historical Society regarded as necessary and worthwhile the publication in 1976 of Carver's original works. William Combe 'edited' John Meares's Voyages Made in the Years 1788 and 1789, from China to the North West Coast of America (I790); his description of what is today the coast of Washington figures prominently in a narrative designed to convince British authorities that they should demand restitution to Meares of ships that the Spaniards had confiscated. Combe's strategy lay in enchantment. If the government ignored Meares's appeal, it would virtually cede the Pacific Coast to Spain, thereby foolishly passing up a claim on Washington state's Mount Olympus - Meares had supplied the empurpled epithet - as well as other delights: 'many beautiful spots, covered with the finest verdure ... [where] the land rose in a very gradual ascent to the distant mountains, skirted by a white sandy beach down to the sea ... spacious lawns and hanging woods everywhere but not an human being to inhabit the fertile country of New Albion. ${ }^{11}$ As 'unknown or ignored'12 as Bicknell's had been in Carver's book, Combe's presence in Meares's narrative was not immediately detected, if only because 'there was nothing unusual about a publisher employing someone to improve a manuscript, and Dr. Johnson's London was well supplied with literary hacks who made their spare livings filling this need.'13

But Combe's work must have met with some attention. It had, after all, helped to decide the British government to send George Vancouver into the Pacific Northwest. Moreover, long before achieving a certain notoriety for himself with the verse satire, The Tour of Dr. Syntax in Search of the Picturesque (1810), Combe was engaged by Alexander Mackenzie to empurple his own fur-trade prospectus, Voyages from Montreal (I80I). The details of this 'collaboration' have been examined at length elsewhere, ${ }^{14}$ and need not detain us here. Suffice it to say that W. Kaye Lamb's edition of the narrative allows one to see that a Grub Street hack, perhaps idling in debtor's prison at the time, envisioned in Old World schemata - 
specifically, the alluring picturesque - several notable western landmarks. Indeed, one might venture that Combe's work as ghost writer could well have furnished the source for some of the lines given to his character, Dr. Syntax, the ape of William Gilpin, the doyen of landscape touring:

With curious eye and active scent

I on the picturesque am bent.

That is my game; I must pursue it,

And make it where I cannot view it. ${ }^{15}$

With their involvement going undetected, Bicknell and Combe supplied the explorers' accounts with an essential dualism, between the plain and the more refined modes of representation of the New World. This dualism would appear as the norm for subsequent generations of explorers in the North-American West. We know that Thomas Jefferson ordered his own copy of Mackenzie's Voyages within a month of having word of its availability in Philadelphia. ${ }^{16}$ Not only were his geopolitical ambitions shaped by the book and London cartographer Aaron Arrowsmith's latest map, of the same year (largely cribbed without acknowledgement from David Thompson), but his notion of how to image the West in a fashion that the East could understand was derived from a source in which a hack was commissioned to create landscapes that would entice the sort of investment that Mackenzie, having helped to establish a new (XY) fur-trade company by the time of his book's publication, was seeking upon his return to London. These depictions erupt into the narrative at intervals, disturbing the linear record of distances achieved and directions taken. Hence the dualism, or 'fissure,' as Fender has termed it; ${ }^{17}$ but whereas Fender finds this circumstance of the literature within the writings done by individual western travellers, I want obviously to suggest that ghost writers had helped to produce it in the first English-language writings about the continent's West.

When Meriwether Lewis extols the Great Falls on the Missouri by invoking the names of Salvator Rosa and James Thomson, ${ }^{18}$ he is conventionally following the canons of aesthetic parlance bestowed by Old World language, but bestowed by publishers' hack writers. It appears that Jefferson had accepted these terms of description; indeed, he had deployed them to some extent himself in his own Notes on Virginia and 'Memorandums Made on a Tour to Some of the Gardens in England' (I 786). That Lewis should have endeavoured in some sense to conform to Jefferson's notions of ideal landscape, derived from the President's own touring in Europe and from Mackenzie's book, is no wonder; neither, however, should one be surprised that Jefferson's selling of the idea of the West to his countrymen by 
way of Lewis's narrative flourishes paralleled Mackenzie's marketing of a similar strategy by way of Combe's. And whatever Lewis had not supplied, ${ }^{19}$ Nicholas Biddle, the Princeton graduate and editor of Port Folio, could, when he undertook to publish the Lewis and Clark journals. Thus, even by the time of Lewis, explorers of the West were themselves unconsciously emulating ghost writers. Their perceptual baggage to some extent was also the ghost writer's bag of trade tools, the tools needed to create out of a journal a narrative that a publisher would agree to market. The commodity of the book of travel literature, like the lithograph of the original sketch or the engraving of the original sketch map, reflected, by the time it appeared for sale, many interests besides those of the explorer or traveller to record routes traversed, peoples encountered, and events witnessed. But if publishers in London and Philadelphia knew that the New World West sold if it was couched in Old World language, they did not interest themselves in altering the profitable status quo. And so, the nineteenth century saw practices harden into formulae, contents alone occasionally distinguishing one book of travel literature from another.

Another book reflecting one of the most extreme disjunctions between original journals and published book is Paul Kane's Wanderings of an Artist Among the Indians of North America, published by Longman in I 859 and based upon the painter's travels from Toronto to Oregon and back between I 846 and I848. Trained partly in Toronto, partly in Mobile, and partly in Italy, Kane was influenced greatly by his viewing of George Catlin's London exhibition of $\mathrm{I} 843 i^{20}$ consequently, he determined to emulate both the American's artistic and his literary achievements for the British North-American West, or so critical studies have said. The execution of the paintings - landscapes as well as now famous portraits of Indian chiefs and squaws - caused Kane no particular trouble, although he invoked only standard picturesque techniques for the most part. The Goetzmanns provide a veritable hodgepodge of critical interpretation by labelling Kane's art 'romantic, if not exotic,' while maintaining not only that he 'really forgot or abandoned most of his European training,' but also that ' $\mathrm{h}]$ is paintings have a rough authenticity about them' that, curiously, is nonetheless 'hardly objective nor ... solely ethnographic. ${ }^{21}$ Kane's art bears witness to the fact that painters also brought the Old World to their impressions of the New, but the Goetzmanns' contradictions seem more snagged by the consequent fissure than aware of it.

Kane's published prose record documents more dualistic contrariety. According to the 'Author's Preface,' Wanderings of an Artist aims both to study the aborigine and, with an almost Wordsworthian fervour, to retrieve an innocent past, when Kane 'had been accustomed to see hundreds of Indians about my native village. ${ }^{22}$ The 'objective' reporter and the 
sentimental traveller thus immediately clash in this persona, and continue to do so in various ways throughout the book. Moreover, the sentimental traveller's attitude towards Amerindians itself undergoes contradictory change as Kane's personal contact with Western tribes, however it allured him as a painter, increasingly repulsed him as the persona of the book.

These dualisms or fissures are further complicated by bibliographical research, which discloses that, far from being able to juggle the various qualities of a complex persona, Kane could write only indifferently and certainly not with much sophistication. The only journals that exist in Kane's own hand are contained in two breastpocket-sized notebooks, now in the collections of the Stark Museum of Art in Orange, Texas. One of these is a chronological journal, the other a complementary series of notes on the characters of Indians and landscapes painted. Even a glancing comparison of passages from the book and the journal can offer discrepancies worthy of consideration: ${ }^{23}$

Found some Indians, who ferried ourselves and baggage in a canoe over the Nezperees River, which is here about 250 yards wide. We swam our horses at the mouth of the Pelouse River [modern Palouse River, a tributary of the Snake, lying in eastern Washington state],

5 where it empties itself into the Nezperees [Snake]. The Chief of this place is named Slo-ce-ar-cum. He wore his hair divided in long masses, stuck together with grease. The tribe do not number more than seventy or eighty warriors, and are called Upputuppets. He told me that there was a fall up the Pelouse that no white man had

Io ever seen, and that he would conduct me up the bed of the river, as it was sufficiently shallow for our horses. I accepted his proposal, and rode eight or ten miles through a wild and savage gorge, composed of dark brown basaltic rocks, heaped in confusion one upon another to the height of I,O00 and I,500 feet, sometimes

I 5 taking the appearance of immense ruins in the distance. At one place the strata assumed the circular form, and somewhat the appearance, of the Colosseum at Rome. Our path, at the bottom of

I 8 this gorge, was very difficult, as it lay through masses of tangled brush and fallen rocks. ${ }^{24}$

i 14 th left at 5 this morning for the river Nepersey and arived at $\mathrm{I} 2$ a distance of $30 \mathrm{~m}$. no water all day. a good plase for a

$\mathrm{v}$ persion with the Hidrafoba this. found sum Indians who 


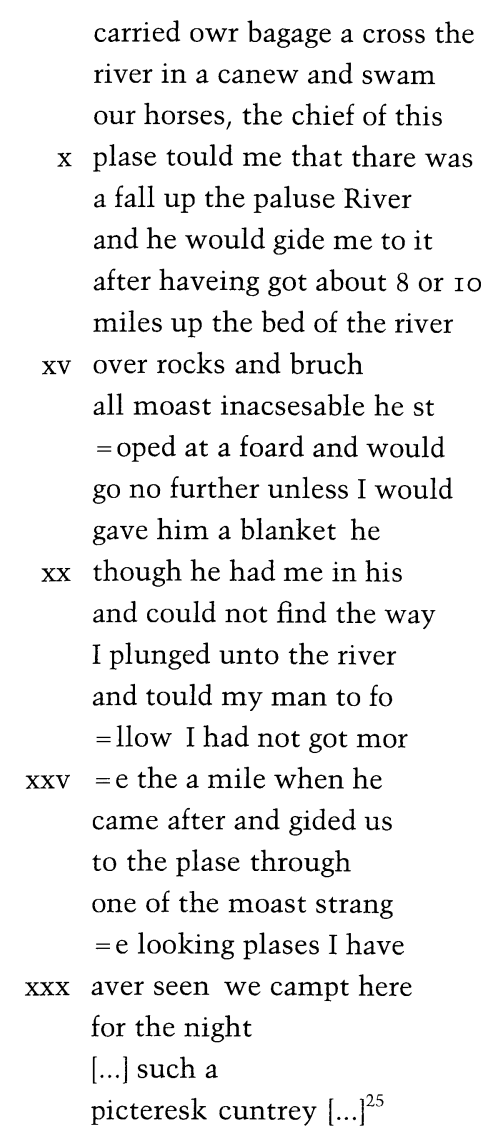

If nothing else, one responds to these two passages by remembering that Kane's published preface included the statement that 'the following pages are the notes of my daily journal, with little alteration from the original wording, as I jotted them down in pencil at the time.' In fact, even the notion of as basic a unit as the sentence appears only occasionally to be firmly grasped by the journalist; the ghost writer's effort not only turns Kane into a gentleman ('I accepted his proposal' [11. II-I2]), specifies the location ('the mouth of the Pelouse river' [1.3]), and corrects the spelling, but transforms the trip into a unique occasion l'a fall ... that no white man had ever seen' [1. 9]). Further, Kane's own humour in the journal ('a good plase for a persion with the Hidrafoba this' [1l. iv-vi]) apparently did not befit the gentleman traveller of the persona, and so is elided. Two other changes occur: designed out of the landscape of the route ('rocks and bruch all moast inacsesable' [11. xv-xvi]), the scene created by the ghost writer 
may be more readily recognized by the Old World reader ('a wild and savage gorge, composed of dark basaltic rocks, heaped in confusion one upon another to the height of I,000 and I,500 feet, sometimes taking the appearance of immense ruins in the distance' [11. I2-I5]). This created landscape bears signs both of an aesthetic and a scientific description, having both the parlance of the sublime (wild, savage, heaped in confusion, appearance of ruins) and the terminology of both amateur geology (basaltic) and geography (the altitudes given). Finally, the Indian chief is named, described both individually and in terms of his tribe, and generally made to suit the book's 'savage' landscape.

One might also wish to note that the ghost writer fashions a sublime landscape out of a scene that Kane regarded as 'picteresk.' These two aesthetic categories were not always deployed in mutual exclusion, but usually some distinction was made between them. True, a painter might well have meant by the term picturesque only, as indeed was Kane's case, ${ }^{26}$ that the scene accorded with his sense of picture-making. In fact, though, Kane did paint picturesque, not sublime, pictures on this side trip; the published account therefore stands at variance with the pictorial oeuvre.

The ghost writer did more: he created portions of the literary itinerary where Kane's journals and log of notes simply fell silent. An important addition to them is the beginning of the book's twenty-first chapter, which advertises 'Dreadful Tidings - Horrible Tragedy.' This chapter tells of the news of the Whitman massacre. Kane's published persona hears the news of the incident while on the Columbia at Fort Colville (near the modern international border). It distresses him deeply because the Whitmans had treated him very hospitably when he stayed with them for five days, I 8-22 July, earlier in the summer (1 847). The description of the massacre is fully and dramatically drawn. The problem is that, with the original silent at this point, the ghost writer has Kane learn of the massacre on 'September 2Ist,' or sixty-seven days before it started. ${ }^{27}$ This is prescience indeed. Once alerted to this impossibility, the reader of the book realizes how easily the chapter simply presents a collation - not a very careful one, obviously - of reports that would emerge well before Kane's book was published eleven years later. ${ }^{28}$

One must then wonder about the decision to include the material in the book: did Kane approve of its use, or did the publisher know all too well that any opportunity of dramatizing Indian violence, because it would increase sales of the publication, could not be passed up? These questions remain unanswered, and an allied textual problem remains perplexing: in a book that commences with an avowal to visit 'old friends' and their brethren farther west, the spirit of racism that compromises the book's persona makes little sense. Worse, the journals contain not one pejorative remark 
about any of the Amerindians Kane met; the racism is the ghost writer's / publisher's, not Kane's own. Because Kane has been attacked recently as a racist spouting a discourse of imperialism, ${ }^{29}$ this distinction deserves to be made. Kane's only comment about 'Ta-mach-hus' (Tomahas), one of Marcus Whitman's killers, whom Kane had sketched, ${ }^{30}$ is that 'he has give Dr W a grate dele trubble.' Even as fine an historian as Clifford M. Drury has faltered slightly in this regard: in his biography, Marcus and Narcissa Whitman and the Opening of Old Oregon (I973), Drury cites Kane's book for his interpretation of Whitman's assassins. ${ }^{31}$

Many further changes may be adduced to point up the discrepancy between journal and book. In tidying Kane up into the persona of a gentleman, the book not only provides sentences, paragraphs, and chapters; it also changes incidents (remembers them differently?) and narrates them in an English that the journalist did not know. An interesting example of such alterations is the description of Kane's first sight of buffalo, while he travelled with the Métis west of Fort Garry in June I846. In Wanderings, the Sportsman is 'gratified' with their sight: 'they were the first I had seen, but were too far off for me to join in the sport. ${ }^{32}$ That excuse does not occur in the original, where Kane admits that his excitement provokes foolishness:

when an Indan called out that thare was buffalo to the rite of me I asended a sm $=$ all hill when I saw a band of about 40 cows and they hunters in full chase they ware they first $\mathrm{Bu}$ =ffalow I had ever seene I was not long in turning my horses hed in the derection of thy chase after running about 3 miles I came nere up to a cow my hors became afrade after beating for about 2 Miles more I came close enuff for a $\mathrm{sh}=$ 
ot when I found I

had no ball I fired

shot but without

afect $^{33}$

The book's 'too far off for me to join in the sport' strikes the reader of the journals as a rather lame excuse: it directly contradicts the journal's statement that Kane 'came close enuff for a shot.' Then, his shooting shot without a ball meets with no result. This droll event is edited out of the book: presumably, no sportsman worthy of the name would have been so careless. But the attitude of one who sees buffalo for the first time has also been altered significantly in so far as the book's persona is merely 'gratified,' while the prose of the journal, infected by the excitement of the novelty, sounds like a child's narrative, replete with principal clauses and repetition of the first person singular pronoun. The revision brings the young pup to heel with an atypical sophistication and nonchalance. One is tempted to add that the effect of the alteration bears an analogy to the change effected in Kane's painting, where the heavy, dark colours of the studio oil paintings lend the lively field sketches a subdued and stilted demeanor.) Wanderings of an Artist next pauses to provide a refined, paragraph-long culinary dissection of the buffalo, while the journal remains with its principal concern, if somewhat abashedly: 'this morning I tuck good care that I had plentey off ball.'

When Kane returns to Fort Garry from the buffalo hunt the journal says very little:

... I arived at

fort Garey wet and tired

I here receved word from

the governer that thare

would be 2 Slops leve

the lowr fort far

Norway House bid good

by to my cind host Mr.

Cristey and left for the lowr

Fort ... ${ }^{34}$

By contrast, in Wanderings, after 'Mr. Christie' is thanked rather more fulsomely ('whose many acts of kindness and attention I must ever remember with feelings of grateful respect ${ }^{\prime},{ }^{35}$ a chapter ending of three paragraphs intervenes. Only with the opening of the next chapter does the book's reader hear 'that two small sloops belonging to the Company which ply 
between the Red River and Norway House would leave the Lower, or Stone Fort, immediately. ${ }^{36}$ The intervening paragraphs exploit the occasion of Kane's expression of gratitude to a Company Factor. Whoever wrote them clearly intended to show the Hudson's Bay Company in the best possible light, for the added passage goes on to laud Christie's employer, not the man himself:

The half-breeds are much inclined to grumbling, and although the Company treat them with great liberality, they still ask almost for impossibilities; indeed, as far as the Company is concerned, I cannot conceive a more just and strict course than that which they pursue in the conduct of the whole of their immense traffic. In times of scarcity they help all around them, in sickness they furnish them with medicines, and even try to act as mediators between hostile bands of Indians. No drunkenness or debauchery is seen around their posts, and so strict is their prohibition of liquor, that even their officers can only procure a small allowance, which is given as part of their annual outfit on voyages. ${ }^{37}$

Kane certainly owed the opportunity of his travels to the hospitality of the Company, but, given that there is no source in the journals for this paean, it appears that the Company was exacting a sort of repayment by using the occasion of a book, ostensibly authored by one who stood at arm's length from the Company, to propagate a glowing portrait of itself.

The date of publication - March r859-takes on added significance here, inasmuch as the Hudson's Bay Company had not yet entirely given up hope of obtaining from the British Parliament another renewal of its exclusive right to trade in the Northwest. An objective opinion advanced freely by a disinterested gentleman - perhaps the book's conversion of Kane's persona to a gentleman takes on a further significance in this connection - could only abet the Company's efforts. Thus the passage continues, no longer disguising its aims:

Without entering into the general question of the policy of giving a monopoly of the fur trade to one company, I cannot but record, as the firm conviction which I formed from a comparison between the Indians in the Hudson's Bay Company territories and those in the United States, that opening up the trade with the Indians to all who wish indiscriminately to engage in it, must lead to their annihilation. For while it is the interest of such a body as the Hudson's Bay Company to improve the Indians and encourage them to industry, according to their own native habits in hunting and the chase, even with a view to their own profit, it is as obviously the interest of the small companies and private adventurers to draw as much wealth as they possibly 
can from the country in the shortest possible time, although in doing so the very source from which the wealth springs should be destroyed. The unfortunate craving for intoxicating liquor which characterizes all the tribes of Indians, and the terrible effects thereby produced upon them, render it a deadly instrument in the hands of designing men.

It is well known that, although the laws of the United States strictly prohibit the sale of liquor to the Indians, it is impossible to enforce them, and whilst many traders are making rapid fortunes in their territories, the Indians are fast declining in character, numbers, and wealth, whilst those in contact with the Hudson's Bay Company maintain their numbers, retain native characteristics unimpaired, and in some degree share in the advantages which civilization places within their reach. ${ }^{38}$

The rhetorical force of the contrasting tricolons at the conclusion of this chapter-ending passage ('character' vs. 'characteristics,' 'numbers' vs. 'numbers,' and 'wealth' vs. 'share in advantages' - this last a rather disingenuous shift of emphasis from monetary wealth to social wealth) reminds the reader of the severity of the Company's struggle in I859 to maintain the status quo. At this stage of Kane's book, a Company's apologia and, as it was perhaps hoped, its prospectus, ambush and co-opt an independent traveller's narrative. This passage marks another extreme, where the original voice of Kane is not present at all.

As the variety of these textual comparisons testifies, it seems worthwhile maintaining that bibliographical study precede interpretation of Kane's book as well as other books of travel and exploration literature. Occasionally, a dualism occurs, as with Hearne, in a writer's own multiple versions of his expedition; as with Meriwether Lewis, the dualism issues out of an emulation of a trait discernible in earlier publications. Often, in the case of published books, and certainly in the case of Wanderings of an Artist Among the Indians of North America, the dualism arises, I think, as a consequence of multiple authorship. ${ }^{39}$

In conclusion one must offer further speculation on the reasons, both in the case of specific texts and in general, for the changes between field book and published book, and here one reverts to the matter of audience. Publishers in both England and the United States sold works of travel at high prices; indeed, most travel literature sold as an elite genre, penned by the well-to-do, or for them as the patrons of the explorers themselves. That the travelling persona metamorphoses into a gentleman in Kane's case, then, or into a sentimental, acculturated human in Hearne's case may also be regarded as the publisher's shrewd recognition of the need to situate his greatest number of readers comfortably in the text. No penny dreadfuls, published works of travel literature were made to mirror the world that 
gentlemen and ladies saw, or which they at least were thought to see. Not just a discourse of imperialism, then, but a discourse of class can be traced in nineteenth-century travel writing, as the New World is made over in the image of the Old.

NOTES

I wish to acknowledge with thanks the co-operation of the Nelda C. and H.J.

Lutcher Stark Foundation, and the assistance of Anna Jean Caffey, Registrar, Stark Museum of Art, Orange, Texas.

I See, for example, Charles L. Batten, Jr., Pleasurable Instruction: Form and Convention in Eighteenth-Century Travel Literature (Berkeley and Los Angeles: University of California Press, 1978).

2 See Barbara Maria Stafford, Voyage Into Substance: Art, Science, Nature, and the Illustrated Travel Account, 1760-1840 (Cambridge, Mass.: Mit Press, 1984).

3 Stephen Fender, Plotting the Golden West: American Literature and the Rhetoric of the California Trail (Cambridge: Cambridge University Press, I98 I), pp. 7, I3, I6.

4 N.N. Feltes, Modes of Production of Victorian Novels (Chicago: University of Chicago Press, I986).

5 Samuel Hearne, A Journey from Prince of Wales's Fort in Hudson's Bay to the Northern Ocean 1769, 1770, 1771, 1772, ed. Richard C. Glover (Toronto: Macmillan, I9581, p. xliii.

6 This statement arises as a conclusion out of research done at the archive of John Murray, still located at 50 Albemarle Street, London. Especially during the early nineteenth century, correspondence between John Murray II and explorers shows that 'readying' the manuscript for publication was referred to often by both authors and publisher. Report of this finding, more a confirmation at that, has not at this point been published.

7 Samuel Hearne, Journey, p. xxxix.

8 Ibid., p. гоo.

9 Ibid., p. Ioon.

Io On this subject, see Ian MacLaren, 'Samuel Hearne and the Landscapes of Discovery,' Canadian Literature, no. I03 (Winter 1984): 27-40.

I I John Meares, Voyages Made in the Years 1788 and 1789, from China to the North West Coast of America. To Which Are Prefaced, an Introductory Narrative of a Voyage Performed in 1786, from Bengal, in the Ship Nootka; Observations on the Probable Existence of a North West Passage; and Some Account of the Trade Between the North West Coast of America and China; and the Latter Country and Great Britain (1790; reprint ed., Amsterdam: N. Israel; New York: Da Capo, I967), p. I68.

I2 Jonathan Carver, The Journals of Jonathan Carver and Related Documents 1766- 
1770, ed. John Parker (St. Paul: Minnesota Historical Society, I976), p. 32.

I3 Ibid.

I 4 I.S. MacLaren, 'Alexander Mackenzie and the Landscapes of Commerce,' Studies in Canadian Literature 7 (1982): I4 I-50.

I5 John Dixon Hunt and Peter Willis, eds., The Genius of Place: The English Landscape Garden 1620-1820 (London: Paul Elek, I975), p. 370.

I6 John L. Allen, 'To Unite the Discoveries: The American Response to the Early Exploration of Rupert's Land,' in Rupert's Land: A Cultural Tapestry, ed. Richard C. Davis (Waterloo: Wilfrid Laurier University Press, I988), p. 79.

I7 Fender, Plotting the Golden West, p. I4.

I 8 See Robert Edson Lee, From West to East: Studies in the Literature of the American West (Urbana: University of Illinois Press, I966), p. 24.

I9 See Robert Lawson-Peebles, The World Turned Upside Down: Landscape and Written Expression in Revolutionary America (Cambridge: Cambridge University Press, I9881, ch. 6.

20 J. Russell Harper, ed., introd., and with a cat. raissoné, Paul Kane's Frontier (Toronto: University of Toronto Press, for the Amon Carter Museum and the National Gallery of Canada, I97r), p. I3.

2 I William H. Goetzmann and William N. Goetzmann, The West of the Imagination (New York: Norton, I986), p. 42.

22 Paul Kane, Wanderings of an Artist Among the Indians of North America from Canada to Vancouver's Island and Oregon Through the Hudson's Bay Company's Territory and Back Again (1859; rev. ed. by John W. Garvin, introd. by Lawrence W. Burpee. Toronto: Radisson Society of Canada, I925; reprint, introd. by J.G. MacGregor, Edmonton: Hurtig, I 968), p. lxii.

23 A full biographical discussion is available in I.S. MacLaren, 'Notes Towards a Reconsideration of Paul Kane's Art and Prose,' Canadian Literature, nos. I I 3-I I 4 (Summer / Fall I987): 179-205.

24 Kane, Wanderings, p. I9I.

25 Stark Museum of Art, accession I I.85/5, pp. [58-6o].

26 Cf. Harper, Paul Kane's Frontier, Plate xxxv.

27 Harper does note this chronological error in the book, but does not follow up his remark that Kane is 'curiously in error about dates' (p. 23).

28 Kane was nearly at Fort Edmonton for the winter when the massacre occurred, and at Fort Edmonton by ro Dec., when the Oregon Spectator published the first report of it. Because he had barely managed the crossing of the mountains on the last eastward fur-trade brigade of the season, it is difficult to countenance the idea that he knew of the massacre through the winter of $1847-48$. Indeed, as he left Fort Edmonton early the next spring, Kane may well have not learned the fate of the Whitmans until his arrival back in civilization at Toronto, in the autumn of I 848 .

29 Heather Dawkins, 'Paul Kane and the Eye of Power: Racism in Canadian Art History,' Vanguard I 5 (Sept. I986): 24-7. 
30 Harper, Paul Kane's Frontier, IV-364 and Iv-365 (p. 296).

3 I Clifford M. Drury, Marcus and Narcissa Whitman and the Opening of Old Oregon, 2 vols. (Glendale, Cal.: Arthur N. Clark, I 973), 2: 72-3.

32 Kane, Wanderings, p. 56.

33 Stark Museum of Art, accession I I.85/5, pp. [I3-I4].

34 Ibid., pp. [27-8].

35 Kane, Wanderings, p. 65.

36 Ibid., p. 67.

37 Ibid., p. 65 .

38 Ibid., p. 65-6.

39 As reported in MacLaren, 'Reconsideration,' correspondence with Michael Bott, Keeper of Archives and Manuscripts, University of Reading, confirms that the Longman archive, located there, contains only very limited holdings pertaining to Kane's book. These consist only of ledger entries. 